\title{
Setosphlides A-D, New Isocoumarin Derivatives from the Entomogenous Fungus Setosphaeria rostrate LGWB-10
}

\author{
Wenbin Gao ${ }^{1} \cdot$ Xiaoxia Wang ${ }^{1} \cdot$ Fengli Chen ${ }^{1} \cdot$ Chunqing $\mathrm{Li}^{1} \cdot$ Fei Cao $^{1} \cdot$ Duqiang Luo ${ }^{1}$
}

Received: 1 October 2020 / Accepted: 8 December 2020 / Published online: 7 January 2021

(c) The Author(s) 2021

\begin{abstract}
Investigation of the entomogenous fungus Setosphaeria rostrate LGWB-10 from Harmonia axyridis led to the isolation of four new isocoumarin derivatives, setosphlides A-D (1-4), and four known analogues (5-8). Their planar structures and the relative configurations were elucidated by comprehensive spectroscopic methods. The absolute configurations of isocoumarin nucleus for 1-4 were elucidated by their ECD spectra. The C-10 relative configurations for the pair of C-10 epimers ( $\mathbf{1}$ and 2) were established by comparing the magnitude of the computed ${ }^{13} \mathrm{C}$ NMR chemical shifts $\left(\Delta \delta_{\text {calcd. }}\right)$ with the experimental ${ }^{13} \mathrm{C}$ NMR values $\left(\Delta \delta_{\text {exp. }}\right)$ for the epimers. All of the isolated compounds (1-8) were evaluated for their cytotoxicities against four human tumor cell lines MCF-7, MGC-803, HeLa, and Huh-7.
\end{abstract}

\section{Graphic Abstract}
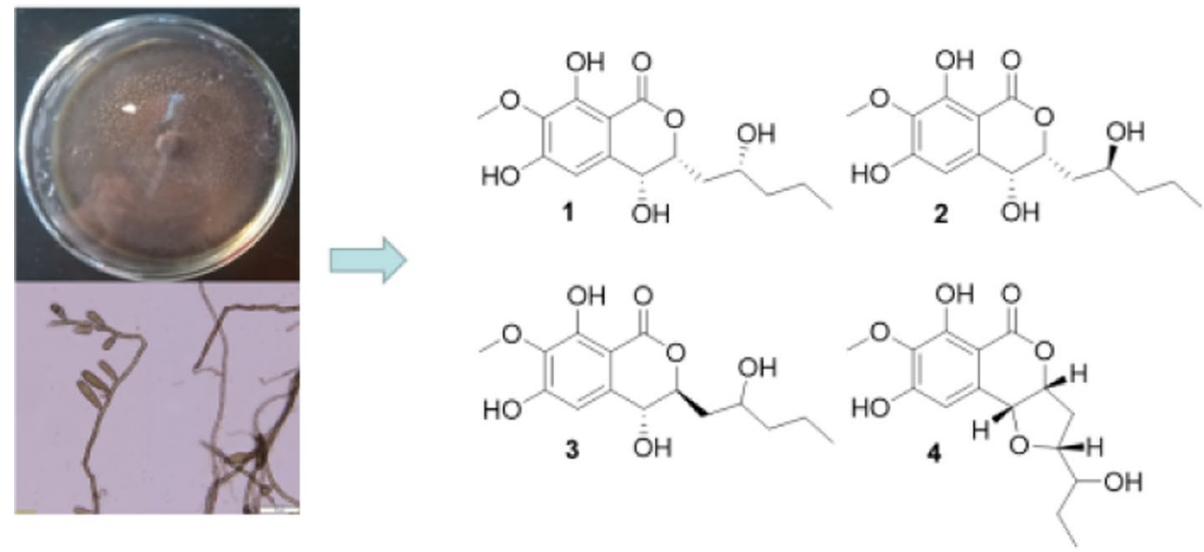

Keywords Entomogenous fungus $\cdot$ Setosphaeria rostrate $\cdot$ Isocoumarin $\cdot$ Absolute configuration

In Honor of Professor Jun Zhou.

Supplementary Information The online version of this article (https://doi.org/10.1007/s13659-020-00292-8) contains

supplementary material, which is available to authorized users.

Fei Cao

caofei542927001@163.com

Duqiang Luo

duqiangluo@163.com

1 College of Life Science, Institute of Life Science and Green Development, Key Laboratory of Medicinal Chemistry and Molecular Diagnosis of Ministry of Education, Hebei University, Baoding 071002, China

\section{Introduction}

Symbiosic microorganisms from insects, which are wellknown as a rich source of bioactive natural products, have attracted widespread attention [1-3]. Especially, due to the special environmental conditions, the bioactive natural products from symbiotic microorganisms as a rich source of various compounds with complex structures and excellent activities, may reshape the experts' views on the drug ability of natural products [4]. Among them, isocoumarin derivatives have been isolated as antifungal, insecticidal, and phytotoxic 
secondary metabolites from several fungal sources [5]. However, it made such a task extremely challenging to assign their absolute configurations, when a side chain attached to isocoumarin derivative nuclear, as the high free rotation of the stereogenic centers in chains [6]. During our ongoing search for bioactive compounds from fungi, Setosphaeria rostrate LGWB-10 was selected for chemical exploration based on HPLC-DAD and HPLC-MS analyses of its EtOAc extract. Subsequently, eight isocoumarin derivatives, including four new setosphlides A-D (1-4) and four known analogues, $(3 R, 4 R)-4,8$-dihydroxy-3-((R)-2-hydroxypentyl)6,7-dimethoxyisochroman-1-one (5) [5], (3R,4R)-4,8-dihydroxy-3-((R)-2-hydroxypentyl)-6,7-dimethoxyisochroman1-one (6) [5], (12R)-12-hydroxymonocerin (7) [7], and (12S)-12-hydroxymonocerin (8) [6] (Fig. 1) were isolated from Setosphaeria rostrate LGWB-10. Herein, we report the details of the isolation, structure elucidation, absolute configuration determination, and bioactivities of them.

\section{Results and Discussion}

Setosphlide A (1) was isolated as a colorless oil. The molecular formula of $\mathbf{1}$ was determined as $\mathrm{C}_{15} \mathrm{H}_{20} \mathrm{O}_{7}$ by positive HRESIMS data at $\mathrm{m} / z 335.1093[\mathrm{M}+\mathrm{Na}]^{+}$(calcd. for 335.1101), with six indices of hydrogen deficiency. Analysis of the 1D NMR and HSQC data of $\mathbf{1}$ (Table 1) revealed the presence of two methyl groups $\left(\delta_{\mathrm{H}} 3.85\right.$ and 0.96$)$, three methylene groups $\left(\delta_{\mathrm{H}} 1.50\right.$ and $1.42,2.13$ and 1.65, and $1.50)$, three oxygen-bearing methine groups $\left(\delta_{\mathrm{H}} 4.70,4.42\right.$, and 3.91), and one olefinic proton $\left(\delta_{\mathrm{H}} 6.49\right)$. Analysis of ${ }^{13} \mathrm{C}$ NMR and HMBC spectra of $\mathbf{1}$ (Table 2) indicated the presence of 15 carbons, including six quaternary carbons $\left(\delta_{\mathrm{C}}\right.$ $171.2,158.5,157.4,139.1,136.3$, and 101.5), four methines $\left(\delta_{\mathrm{C}} 108.5,80.6,67.8\right.$, and 67.7$)$, three methylenes $\left(\delta_{\mathrm{C}} 41.5\right.$, 39.5, and 19.9), and two methyls ( $\delta_{\mathrm{C}} 60.9$ and 14.4). Six aromatic carbon signals in the region of $\delta_{\mathrm{C}} 101.5-158.5$ indicated the existence of a polysubstituted phenyl moiety. All of the proton resonances were assigned to the relevant carbon

$\mathrm{Fi}$<smiles>CCC(O)[C@@H](O)C[C@H]1OC(=O)c2c(cc(O)c(O[14CH3])c2O)[C@H]1O</smiles><smiles>CCC(O)[C@H]1C[C@@H]2OC(=O)c3c(cc(O)c(OC)c3O)[C@H]2O1</smiles><smiles></smiles>

Fig. 1 The chemical structures of compounds 1-8<smiles>CCC[C@H](O)C[C@H]1OC(=O)c2c(cc(OC)c(OC)c2O)[C@H]1O</smiles><smiles>CCC[C@H](O)C[C@H]1OC(=O)c2c(cc(OC)c(OC)c2O)[C@@H]1O</smiles><smiles>CCCC(O)C[C@H]1OC(=O)c2c(cc(O)c(OC)c2O)[C@H]1O</smiles>

3<smiles>CCC[C@H](O)C[C@H]1OC(=O)c2c(cc(O)c(OC)c2O)[C@@H]1O</smiles>

2<smiles>CC[C@H](O)[C@H]1C[C@H]2OC(=O)c3c(cc(OC)c(OC)c3O)[C@H]2O1</smiles> 
Table $1{ }^{1} \mathrm{H}$ NMR Data $(\delta)$ of 1-4 $\left(600 \mathrm{MHz}, \mathrm{CD}_{3} \mathrm{OD}, \mathrm{J}\right.$ in $\mathrm{Hz})$

\begin{tabular}{lllll}
\hline No. & $\mathbf{1}$ & $\mathbf{2}$ & $\mathbf{3}$ & $\mathbf{4}$ \\
\hline 3 & $4.70, \mathrm{td}(10.2,1.8)$ & $4.66, \mathrm{td}(6.6,1.8)$ & $4.53, \mathrm{~m}$ & $5.09, \mathrm{dd}(6.0,3.0)$ \\
4 & $4.42, \mathrm{~d}(1.8)$ & $4.52, \mathrm{~d}(1.8)$ & $4.56, \mathrm{~m}$ (overlap) & $4.59, \mathrm{~d}(3.0)$ \\
5 & $6.49, \mathrm{~s}$ & $6.50, \mathrm{~s}$ & $6.58, \mathrm{~s}$ & $6.55, \mathrm{~s}$ \\
9 & $2.13, \mathrm{ddd}(14.4,8.4,1.8)$ & $2.10, \mathrm{ddd}(14.4,8.4,4.2)$ & $1.91, \mathrm{ddd}(15.0,10.8,5.4)$ & $2.55, \mathrm{~m}$ \\
& $1.65, \mathrm{ddd}(14.4,10.2,2.4)$ & $1.97, \mathrm{ddd}(14.4,9.0,6.6)$ & $1.86, \mathrm{ddd}(15.0,13.2,6.0)$ & $2.18, \mathrm{dd}(14.4,6.0)$ \\
10 & $3.91, \mathrm{~m}$ & $3.84, \mathrm{~m}$ & $3.81, \mathrm{~m}$ & $4.00, \mathrm{dt}(9.0,6.0)$ \\
11 & $1.50, \mathrm{~m}$ & $1.52, \mathrm{~m}$ & $1.48, \mathrm{~m}$ & $3.43, \mathrm{~m}$ \\
12 & $1.50, \mathrm{~m}$ & $1.52, \mathrm{~m}$ & $1.48, \mathrm{~m}$ & $1.53, \mathrm{~m}$ \\
& $1.42, \mathrm{~m}$ & $1.47, \mathrm{~m}$ & $1.36, \mathrm{~m}$ & $1.39, \mathrm{~m}$ \\
13 & $0.96, \mathrm{t}(7.2)$ & $0.96, \mathrm{t}(7.2)$ & $0.96, \mathrm{t}(7.2)$ & $0.98, \mathrm{t}(7.2)$ \\
14 & $3.85, \mathrm{~s}$ & $3.85, \mathrm{~s}$ & $3.81, \mathrm{~s}$ & $3.83, \mathrm{~s}$
\end{tabular}

Table $2{ }^{13} \mathrm{C}$ NMR Data $(\delta)$ of $\mathbf{1}-\mathbf{4}\left(150 \mathrm{MHz}, \mathrm{CD}_{3} \mathrm{OD}\right)$

\begin{tabular}{lcccc}
\hline No. & $\mathbf{1}$ & $\mathbf{2}$ & $\mathbf{3}$ & $\mathbf{4}$ \\
\hline 1 & $171.2, \mathrm{C}$ & $171.3, \mathrm{C}$ & $170.3, \mathrm{C}$ & $169.8, \mathrm{C}$ \\
3 & $80.6, \mathrm{CH}$ & $81.3, \mathrm{CH}$ & $82.9, \mathrm{CH}$ & $82.7, \mathrm{CH}$ \\
4 & $67.8, \mathrm{CH}$ & $66.1, \mathrm{CH}$ & $68.2, \mathrm{CH}$ & $75.7, \mathrm{C}$ \\
$4 \mathrm{a}$ & $139.1, \mathrm{C}$ & $139.0, \mathrm{C}$ & $139.7, \mathrm{C}$ & $132.9, \mathrm{C}$ \\
5 & $108.5, \mathrm{CH}$ & $108.7, \mathrm{CH}$ & $107.2, \mathrm{CH}$ & $110.5, \mathrm{CH}$ \\
6 & $158.5, \mathrm{C}$ & $158.5, \mathrm{C}$ & $158.8, \mathrm{C}$ & $158.4, \mathrm{C}$ \\
7 & $136.3, \mathrm{C}$ & $136.4, \mathrm{C}$ & $135.9, \mathrm{C}$ & $136.9, \mathrm{C}$ \\
8 & $157.4, \mathrm{C}$ & $157.4, \mathrm{C}$ & $157.4, \mathrm{C}$ & $157.6, \mathrm{C}$ \\
$8 \mathrm{a}$ & $101.5, \mathrm{C}$ & $101.6, \mathrm{C}$ & $101.0, \mathrm{C}$ & $101.6, \mathrm{C}$ \\
9 & $39.5, \mathrm{CH}_{2}$ & $38.7, \mathrm{CH}_{2}$ & $40.5, \mathrm{CH}_{2}$ & $36.8, \mathrm{CH}$ \\
10 & $67.7, \mathrm{CH}_{2}$ & $68.5, \mathrm{CH}^{2}$ & $69.0, \mathrm{CH}^{2}$ & $82.8, \mathrm{CH}^{-}$ \\
11 & $41.5, \mathrm{CH}_{2}$ & $40.9, \mathrm{CH}_{2}$ & $40.2, \mathrm{CH}_{2}$ & $75.6, \mathrm{CH}^{-}$ \\
12 & $19.9, \mathrm{CH}_{2}$ & $19.9, \mathrm{CH}_{2}$ & $19.7, \mathrm{CH}_{2}$ & $26.9, \mathrm{CH}_{2}$ \\
13 & $14.4, \mathrm{CH}_{3}$ & $14.4, \mathrm{CH}_{3}$ & $14.3, \mathrm{CH}_{3}$ & $10.5, \mathrm{CH}_{3}$ \\
14 & $60.9, \mathrm{CH}_{3}$ & $60.9, \mathrm{CH}_{3}$ & $60.9, \mathrm{CH}_{3}$ & $60.9, \mathrm{CH}_{3}$ \\
\hline
\end{tabular}

atoms by the HSQC spectrum. Careful comparison of the ${ }^{1} \mathrm{H}$ and ${ }^{13} \mathrm{C}$ NMR spectra as well as the MS data of $\mathbf{1}$ with those of $(3 R, 4 R)-4,8$-dihydroxy-3-((R)-2-hydroxypentyl)-6,7dimethoxyisochroman-1-one (5) [5], revealed that 1 shared the same scaffold as $\mathbf{5}$. The detailed comparison of 1D NMR data between $\mathbf{1}$ and $\mathbf{5}$ suggested the $6-\mathrm{OCH}_{3}$ in $\mathbf{5}$ was absent in $\mathbf{1}$, which was confirmed by the key HMBC correlations from $\mathrm{H}-5$ and $7-\mathrm{OCH}_{3}$ to C-4, C-7 and C-15 (Fig. 2). Thus, the planar structure of $\mathbf{1}$ was assigned.

Setosphlides B and C ( $\mathbf{2}$ and $\mathbf{3}$ ) were obtained with the same molecular formula of $\mathbf{1}$. Furthermore, the ${ }^{1} \mathrm{H}$ and ${ }^{13} \mathrm{C}$ NMR data of 1-3 (Tables 1 and 2) showed striking similarity, suggesting the same structural nucleus of them. In fact, only differences of the NMR signals for $\mathrm{CH}-3, \mathrm{CH}-4$, and $\mathrm{CH}-10$ were observed $\left[\delta_{\mathrm{H}} 4.70(1 \mathrm{H}, \mathrm{td}, J=10.2,1.8 \mathrm{~Hz}\right.$, $\mathrm{H}-3), 4.42(1 \mathrm{H}, \mathrm{d}, J=1.8 \mathrm{~Hz}, \mathrm{H}-4), 3.91(1 \mathrm{H}, \mathrm{m}, \mathrm{H}-10), \delta_{\mathrm{C}}$ $80.6(\mathrm{C}-3), 67.8(\mathrm{C}-4)$, and $67.7(\mathrm{C}-10)$ in 1 vs. $\delta_{\mathrm{H}} 4.66(1 \mathrm{H}$, $\mathrm{dt}, J=6.6,1.8 \mathrm{~Hz}, \mathrm{H}-3), 4.52(1 \mathrm{H}, \mathrm{d}, J=1.8 \mathrm{~Hz}, \mathrm{H}-4), 3.84$
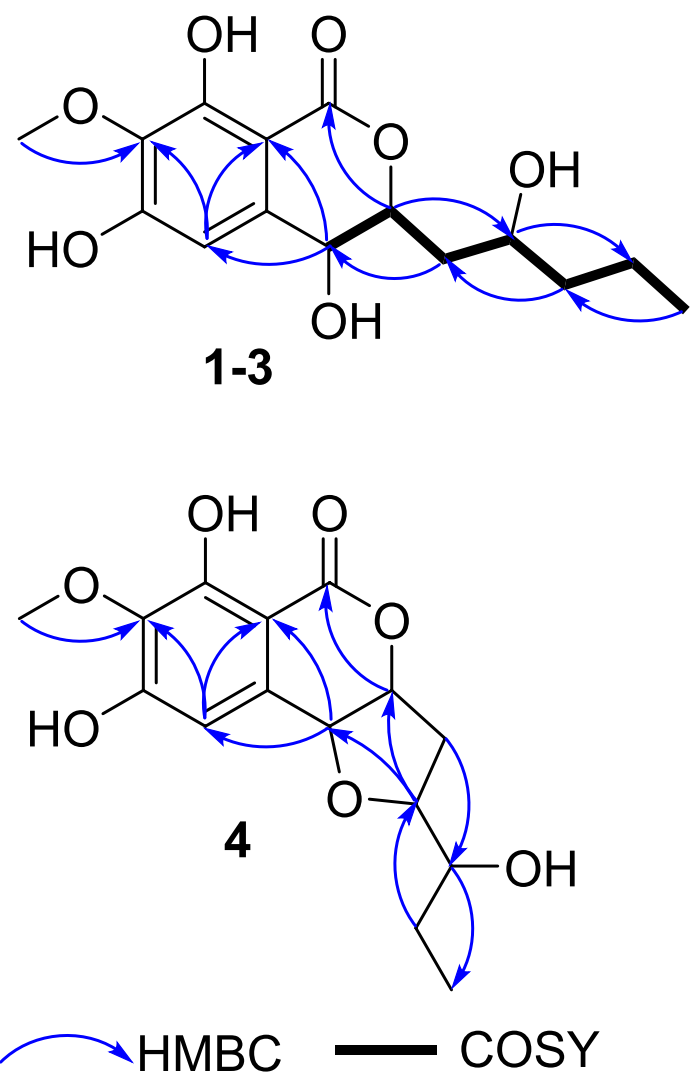

Fig. $2{ }^{1} \mathrm{H}-{ }^{1} \mathrm{H}$ COSY and Key HMBC correlations of 1-4

$(1 \mathrm{H}, \mathrm{m}, \mathrm{H}-10), \delta_{\mathrm{C}} 81.3(\mathrm{C}-3), 66.1(\mathrm{C}-4)$, and $68.5(\mathrm{C}-10)$ in 2 vs. $\delta_{\mathrm{H}} 4.53(1 \mathrm{H}, \mathrm{m}), 4.56(1 \mathrm{H}, \mathrm{m}), 3.81(1 \mathrm{H}, \mathrm{m}, \mathrm{H}-10), \delta_{\mathrm{C}}$ 82.9 (C-3), 68.2 (C-4), and 69.0 (C-10) in 3], indicating that 1-3 were epimeric isocoumarin derivatives with structural difference at C-3, C-4, and C-10. The above deduction was confirmed by a detailed analysis of the HSQC, ${ }^{1} \mathrm{H}-{ }^{1} \mathrm{H} \mathrm{COSY}$, and HMBC spectra (Fig. 2).

The relative configurations of C-3 and C-4 in 1-3 were determined by their NOESY correlations. For compounds 1 and 2, NOE correlations from $\mathrm{H}-3$ to $\mathrm{H}-4$ were observed. 


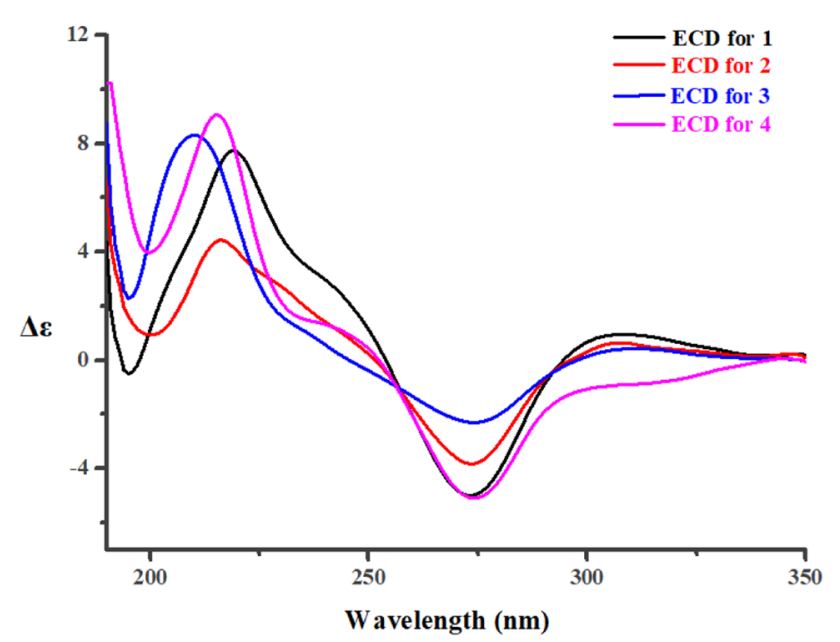

Fig. 3 Experimental CD spectra of $\mathbf{1 - 4}$

While, the NOESY correlations between $\mathrm{H}-4$ and $\mathrm{H}_{2}-9$ were present for 3 . In order to assign the absolute configurations of C-3 and C-4 in 1-3, electronic circular dichroism (ECD) was carried out for them. The absolute configurations of the C-3 methine carbon in 1-3 were deduced by the application of the circular dichroism (CD) exciton chirality method. Further more, According to the earlier references [7, 8], the negative ECD Cotton effect for $\mathbf{1}-\mathbf{3}$ around $275 \mathrm{~nm}$ (Fig. 3) indicated the $3 R, 4 R, 3 R, 4 R$, and $3 S, 4 R$ configurations for $\mathbf{1}$, $\mathbf{2}$, and $\mathbf{3}$, respecitively.

However, it was difficult to determine the absolute configuration of C-10 in 1-3 due to the high conformational flexibility of the chains in them. Especially, the experimental ECD spectra of 1-3 were almost identical, indicating that the ECD method had limitations in the assignment of the C-10 absolute configurations for them. Recently, computational methods for atomic chemical shift calculations have been developed and used for the relative configuration identifications of complex natural compounds [9-11]. Compounds $\mathbf{1}$ and $\mathbf{2}$ are a pair of epimers with more than one stereogenic carbon. The carbons near C-10 in 1 should have different chemical shifts from those of the corresponding carbons in $\mathbf{2}$. Thus, the configurations at C-10 of $\mathbf{1}$ and 2 could be established by comparing the magnitude of the computed chemical shifts $\left(\Delta \delta_{\text {calcd. }}\right)$ for two epimers of $(10 R)$ epimer and (10S)-epimer [12]. The relative errors $\left(\Delta \delta_{\text {calcd. }}\right)$ between the computed ${ }^{13} \mathrm{C}$ chemical shifts of (10R)-epimer and (10S)-epimer, and the relative errors $\left(\Delta \delta_{\text {exp. }}\right)$ between experimental ${ }^{13} \mathrm{C}$ NMR data of $\mathbf{1}$ and $\mathbf{2}$ were summarized in Table 3. Based on the relative error magnitudes $\left(\Delta \delta_{\text {calcd. }}\right.$ and $\Delta \delta_{\text {exp }}$.), the configurations of C-10 for $\mathbf{1}$ and $\mathbf{2}$ were suggested to be $R$ and $S$, respectively. However, the absolute configuration at $\mathrm{C}-10$ in $\mathbf{4}$ was undetermined since only one of its C-10 epimer was not obtained.
Table 3 Chemical shift differences of selected carbons in 1 and 2

\begin{tabular}{lll}
\hline No. & $\begin{array}{l}\text { Experi- } \\
\text { mental } \\
\Delta \delta_{\text {exp }}\end{array}$ & $\begin{array}{l}\text { Calculated } \\
\Delta \delta_{\text {calcd }}\end{array}$ \\
& $\mathbf{1 - 2}$ & $\begin{array}{l}(10 R)- \\
\text { epimer- } \\
(10 S)- \\
\text { epimer }\end{array}$ \\
\hline C-3 & -0.7 & -0.3 \\
C-4 & 1.7 & 2.1 \\
C-10 & 0.8 & 0.6 \\
C-11 & -0.8 & -1.4 \\
C-12 & 0.6 & 2.3 \\
\hline
\end{tabular}

Setosphlide D (4) was also isolated as a colourless oil with the molecular formula $\mathrm{C}_{15} \mathrm{H}_{18} \mathrm{O}_{7}$ determined by HRESIMS. The NMR spectra (Tables 1 and 2) of $\mathbf{4}$ showed a high similarity to those of 1-3. The most significant difference in the ${ }^{1} \mathrm{H}$ NMR spectra was the presence of an additional methine signal at $\delta_{\mathrm{H}}(3.43, \mathrm{~m})$ in 4 . Furthermore, the key HMBC from $\mathrm{H}-9$ to C-4 indicated that C-4 and C-9 were connected via an oxygen bridge, forming the third ring, a furan $\mathrm{C}$-ring. The relative configuration of C-3, C-4, and C-10 of 4 was determined by NOESY experiment, which showed NOE correlations from $\mathrm{H}-10$ to $\mathrm{H}-3$ and $\mathrm{H}-4$. ECD spectrum suggested the $3 R, 4 R, 10 R$ configuration of 4 (Fig. 3).

All of the isolated compounds (1-4) were evaluated for their cytotoxicities against four human tumor cell lines MCF7, MGC-803, HeLa, and Huh-7. However, all of the compounds hardly displayed obvious activity $\left(\mathrm{IC}_{50}>200 \mu \mathrm{M}\right)$.

\section{Experimental}

\subsection{General Experimental Procedures}

OR and UV data were acquired on Perkin-Elmer 341 and 241 spectrophotometers, respectively. ECD spectra were measured using a JASCO J-715 spectrometer. 1D and 2D NMR data were recorded on a Bruker AM-600 spectrometer. HRESIMS spectra were recorded on a Bruker apex-ultra 7.0T spectrometer. HPLC was carried out on a Waters 600-2489 with a YMC column (YMC-Pack ODSA, $250 \times 10 \mathrm{~mm}$ ). Column chromatography $(\mathrm{CC})$ were conducted over silica gel (200-300 mesh) and Sephadex LH-20 gel $(25-100 \mu \mathrm{m})$. TLC were conducted with silica gel $\mathrm{GF}_{254}$ plates.

\subsection{Isolation of the Fungal Material}

The fungal strain Setosphaeria rostrate LGWB-10 was isolated from the Harmonia axyridis collected in Baoding, Hebei Province, China. The voucher specimen of the fungus 
was deposited at College of Life Science of Hebei University with Genbank MN 378541. Setosphaeria rostrate was cultured on PDA plate at $28^{\circ} \mathrm{C}$ for 7 days, and then inoculated into a $500 \mathrm{~mL}$ Erlenmeyer flask containing $200 \mathrm{~mL}$ of PDB medium. Flask cultures were incubated at $28{ }^{\circ} \mathrm{C}$ on a rotary shaker at $120 \mathrm{rpm} / \mathrm{min}$ for 4 days. Solid fermentation was carried out in 100 Erlenmeyer flasks $(500 \mathrm{~mL})$, each containing $100 \mathrm{~g}$ rice, $80 \mathrm{~mL}$ distilled $\mathrm{H}_{2} \mathrm{O}$, and $5 \mathrm{~mL}$ of culture liquid as seed, and incubated at $28{ }^{\circ} \mathrm{C}$ for 40 days. The fermented material was extracted three times with methanol (20 L for each time), and the methanol extract was concentrated in vacuo to yield a yellow oily residue $(132.6 \mathrm{~g})$. This residue was subjected to silica gel column and eluted with a gradient elution of petroleum ether (PE)/EtOAc (100:0, 90:10, 80:20, $60: 40,50: 50,40: 60,20: 80,10: 90,0: 100(\mathrm{v} / \mathrm{v}))$ to obtain nine fractions Frs.1-9. Among these fractions, Fr.3, eluted with 60\% EtOAc-PE (3:2, v:v), was applied to a Sephadex LH-20 $\mathrm{CC}\left(\mathrm{CH}_{2} \mathrm{Cl}_{2} / \mathrm{MeOH}(1: 1, \mathrm{v}: \mathrm{v})\right)$ to remove the pigment to give Fr.3-1 and Fr.3-2. Then, Fr.3-1 was purified by semipreparative HPLC $\left(70 \% \mathrm{MeOH} / \mathrm{H}_{2} \mathrm{O}, 2.0 \mathrm{~mL} / \mathrm{min}\right)$ to give $4(4.2 \mathrm{mg}), 7$ (6.5 mg), and 8 (6.2 mg). Fr.4 was repeatedly purified by Sephadex LH-20, silica gel CC and semipreparative HPLC to afford compounds $1(4.1 \mathrm{mg})$ and $2(4.3 \mathrm{mg})$, $\mathbf{3}(3.5 \mathrm{mg}), \mathbf{5}(3.2 \mathrm{mg})$, and $\mathbf{6}(3.0 \mathrm{mg})$.

Setosphlide A (1): Colorless oil; $[\alpha]_{\mathrm{D}}^{20}+10.2$ (c 1.00, $\mathrm{MeOH}) ; \mathrm{UV}(\mathrm{MeOH}) \lambda_{\max }(\log \varepsilon) 231$ (4.67), 274 (0.48), $306(0.45) \mathrm{nm}$; ECD $(0.50 \mathrm{mM}, \mathrm{MeOH}) \lambda \max (\Delta \varepsilon) 219$ (+7.76), $273(-5.01), 308(+0.95) \mathrm{nm}$; HRESIMS $\mathrm{m} / \mathrm{z}$ $335.1093[\mathrm{M}+\mathrm{Na}]^{+}$(calcd for $\left.\mathrm{C}_{15} \mathrm{H}_{20} \mathrm{O}_{7} \mathrm{Na}, 335.1101\right) .{ }^{1} \mathrm{H}$ and ${ }^{13} \mathrm{C}$ NMR data, see Tables 1 and 2.

Setosphlide B (2): Colorless oil; $[\alpha]_{\mathrm{D}}^{20}+5.7$ ( c 1.00, $\mathrm{MeOH}) ; \mathrm{UV}(\mathrm{MeOH}) \lambda_{\max }(\log \varepsilon) 231$ (4.65), 274 (0.43), $307(0.42) \mathrm{nm}$; ECD $(0.50 \mathrm{mM}, \mathrm{MeOH}) \lambda \max (\Delta \varepsilon) 216$ $(+4.44), 274(-3.83), 308(+0.64) \mathrm{nm}$; HRESIMS $\mathrm{m} / \mathrm{z}$ $311.1090[\mathrm{M}+\mathrm{Na}]^{+}\left(\right.$calcd for $\left.\mathrm{C}_{15} \mathrm{H}_{20} \mathrm{O}_{7} \mathrm{Na}, 335.1101\right) .{ }^{1} \mathrm{H}$ and ${ }^{13} \mathrm{C}$ NMR data, see Tables 1 and 2.

Setosphlide C (3): Colorless oil; $[\alpha]_{\mathrm{D}}^{20}+20.6(c$ 1.00, $\mathrm{MeOH}) ; \mathrm{UV}(\mathrm{MeOH}) \lambda_{\max }(\log \varepsilon) 232$ (4.54), $274(0.43)$, $307(0.44) \mathrm{nm}$; ECD $(0.50 \mathrm{mM}, \mathrm{MeOH}) \lambda \max (\Delta \varepsilon) 210$ $(+24.96), 274(-6.90), 311(+1.26) \mathrm{nm}$; HRESIMS $\mathrm{m} / \mathrm{z}$ $311.1094[\mathrm{M}+\mathrm{Na}]^{+}\left(\right.$calcd for $\left.\mathrm{C}_{15} \mathrm{H}_{20} \mathrm{O}_{7} \mathrm{Na}, 335.1101\right) .{ }^{1} \mathrm{H}$ and ${ }^{13} \mathrm{C}$ NMR data, see Tables 1 and 2.

Setosphlide D (4): Colorless oil; $[\alpha]_{\mathrm{D}}^{20}+15.3$ (c 1.00, $\mathrm{MeOH}) ; \mathrm{UV}(\mathrm{MeOH}) \lambda_{\max }(\log \varepsilon) 233$ (4.54), 275 (2.61), $307(2.84) \mathrm{nm}$; ECD $(0.50 \mathrm{mM}, \mathrm{MeOH}) \lambda \max (\Delta \varepsilon) 215$ $(+9.07), 277(-5.10), 341(-0.01) \mathrm{nm} ;$ HRESIMS $\mathrm{m} / \mathrm{z}$ $311.1125[\mathrm{M}+\mathrm{H}]^{+}$(calcd for $\left.\mathrm{C}_{15} \mathrm{H}_{19} \mathrm{O}_{7}, 311.1120\right) .{ }^{1} \mathrm{H}$ and ${ }^{13} \mathrm{C}$ NMR data, see Tables 1 and 2.

\subsection{Computational Section}

The molecules of (10R)-epimer (1) and (10S)-epimer (2) was constructed and used for conformational searches using the MMFF94S force field by using BARISTA software. A total of 45 stable conformers for 1 and 48 stable conformers for 2 with relative energy within a $10.0 \mathrm{kcal} /$ mol energy window were obtained and optimized at the gas-phase B3LYP/6-311+ G(d) level using the Gaussian 09 package. MPW1PW91 theory at the basis set of B3LYP/6$311+\mathrm{G}(\mathrm{d}, \mathrm{p})$ in the gas phase was applied for ${ }^{13} \mathrm{C}$ NMR calculation for (10R)-epimer (1) and (10S)-epimer (2).

\subsection{Cytotoxity Assay}

The cytotoxicities against human breast cancer (MCF-7), human gastric cancer (MGC-803), cervical cancer (HeLa), and human hepatoma (Huh-7) cell lines were evaluated using the MTT method [13]. Cisplatin was used as a positive control.

Acknowledgements This work was funded by the National Natural Science Foundation of China (31672070) and National Key Research and Development Program of China (2017YFD0201400 and 2017YFD0201401), and the High Performance Computer Center of Hebei University.

\section{Compliance with Ethical Standards}

Conflict of interest The authors declare no conflict of interest.

Open Access This article is licensed under a Creative Commons Attribution 4.0 International License, which permits use, sharing, adaptation, distribution and reproduction in any medium or format, as long as you give appropriate credit to the original author(s) and the source, provide a link to the Creative Commons licence, and indicate if changes were made. The images or other third party material in this article are included in the article's Creative Commons licence, unless indicated otherwise in a credit line to the material. If material is not included in the article's Creative Commons licence and your intended use is not permitted by statutory regulation or exceeds the permitted use, you will need to obtain permission directly from the copyright holder. To view a copy of this licence, visit http://creativecommons.org/licenses/by/4.0/.

\section{References}

1. A.E. Douglas, Annu. Rev. Entomol. 60, 17-34 (2015)

2. Y. Dong, F. Manfredini, G. Dimopoulos, PLoS Pathog. 5, e1000423 (2009)

3. X. Zhang, W. Wei, R. Tan, Sci. China Chem. 58, 1097-1109 (2015)

4. X. Xu, F. Sun, C. Yin, Y. Wang, Y. Zhang, Acta Microbiol. 58, 1126-1140 (2018)

5. W. Zhang, K. Krohn, S. Draeger, B. Schulz, J. Nat. Prod. 71, 1078-1081 (2008)

6. H. Zhu, Current Organic Stereochemistry (Science Presses of China, Beijing, 2009).

7. R. Li, S. Chen, S. Niu, L. Guo, J. Yin, Y. Che, Fitoterapia 96, 88-94 (2014) 
8. X. Pang, X. Liu, J. Yang, X. Zhou, B. Yang, J. Wang, Y. Liu, J. Nat. Prod. 81, 1860-1868 (2018)

9. K. Wolinski, J.F. Hinton, P. Pulay, J. Am. Chem. Soc. 112, 8251$8260(1990)$

10. F. Cao, Z.H. Meng, P. Wang, D.Q. Luo, H.J. Zhu, J. Nat. Prod. 83, 1283-1287 (2020)
11. H.J. Zhu, Organic Stereochemistry-Experimental and Computational Methods (Wiley-VCH, Verlag GmbH \& Co KGaA, Weinheim, 2015).

12. F. Cao, Z.H. Meng, X. Mu, Y.F. Yue, H.J. Zhu, J. Nat. Prod. 82, 386-392 (2019)

13. T. Mosmann, J. Immunol. Methods 65, 55-63 (1983) 